\title{
Genetic Diversity and Phylogenetic Relationship Among Eight Species of Order: Rodentia in Egypt Based on Random Amplified Polymorphic DNA (RAPD) Marker
}

\author{
Fawzeya Abdelhadi Zayed ${ }^{1}$, Sobhy Hasab El-Naby ${ }^{2}$, Fatma Ahmady Al-Zahaby ${ }^{1}$, \\ Sabha EIsayed Elballat ${ }^{1, *}$
}

${ }^{1}$ Zoology Department, Faculty of Science, Zagazig University, Zagazig, Egypt

${ }^{2}$ Zoology Department, Faculty of Science, Minufiya University, Minufiya, Egypt

Email address:

sabhael@yahoo.com (S. E. Elballat)

${ }^{*}$ Corresponding author

\section{To cite this article:}

Fawzeya Abdelhadi Zayed, Sobhy Hasab El-Naby, Fatma Ahmady Al-Zahaby, Sabha Elsayed Elballat. Genetic Diversity and Phylogenetic Relationship Among Eight Species of Order: Rodentia in Egypt Based on Random Amplified Polymorphic DNA (RAPD) Marker. International Journal of Genetics and Genomics. Vol. 8, No. 2, 2020, pp. 54-62. doi: 10.11648/j.ijgg.20200802.11

Received: December 31, 2019; Accepted: January 20, 2020; Published: March 10, 2020

\begin{abstract}
Of all mammals the rodents have an importance and great diversity. The phylogenetic relationships between the different species of the order Rodentia has an interest and investigations for many researchers. The current study suggests the ability of Random Amplified Polymorphic DNA (RAPD)-PCR to estimate the genetic distance and reflect the genetic relations and variability among eight rodent species of order Rodentia in Egypt. After the use of five arbitrary short primers (OPA-4, OPT-7, OPG-2, OPN-4 and OPM-1) to generate polymorphic, reproducible and score able bands. The results explained that, the highest genetic distance 1 was pronounced between Rattus norvegicus and Mus musculus praetextus similarly between Mus musculus domesticus and Rattus norvegicus. This is followed by the genetic distance between Mesocricetus auratus and Mus musculus domesticus as well as between Cavia porcellus and Rattus norvegicus. Nonetheless, the lowest genetic distance 0.31 was noticeable between Mus musculus praetextus and Mus musculus musculus.
\end{abstract}

Keywords: Rodentia, Mus Musculus, Rattus Rattus, Acomys Cahirinus, Mesocricetus Auratus, Cavia Porcellus

\section{Introduction}

Rodents represent more than $40 \%$ of the all living mammalian species. About $5-10 \%$ of the worldwide spreading rodents are major pest species in agricultural and urban localities, consuming significant amounts of agricultural products. Rodents causes food contamination, crops destruction and acts as vectors for certain diseases resulting in dangerous effects on farm production [1-4].

Furthermore, muroide rodents are mostly associated with negative impacts on the surroundings as well as human income, they also contribute positively as models for biomedical research especially after the complete sequencing of the their genome. The classification and identification of rodents particularly within many mammalian species, are very difficult, they require examination of external and internal morphology (like as skull and dentition) which are often biased by age and sex variations and lack of comparative material. The morphological approach used for identification which has usually undertaken by skilled mammalogists even by the use of microscopic analysis requires high-skilled experience to achieve a reliable identification and even so, they failed to go further from a general group of assumed species. Thus, the genetic analyses of rodents were in need to assess both their systematics and population structure [5-8].

Advances in DNA analysis enhanced the researches in mammals particularly rodent's identification, consequently it confirm the classification of specimens to establish a base for future research including the new biological existences. Such DNA analyses also reveal variation patterns in the use of arthropod as a food source by different bat species or diet variation during different physiological periods. DNA analysis even allows describing mixed contents of the 
stomach or the samples of feces to distinguish the preys consumed by a given predator Furthermore and in most cases, the DNA analysis help to confirm the appearance of certain species in areas out of their distributional range such as bats and Artiodactyls [9-17].

Moreover, DNA analysis is very valuable for identification of the traded wild animals (either live, hunted or accidentally killed), or their organs and other biological materials, ranging from body parts of the animal (e.g. skins, skeletons meat, teeth and horns); these must be identified molecularly with its containing DNA trace [18]. The introduction of DNAbased technologies offered the possibility for overcoming and improves the capability of detecting, monitoring and controlling the trade of animals.

Thus, the current investigation was aimed to analyze the genomic DNA structure of some rodent species which belonging to the Order: rodentia in the Egypt in order to clarify the genetic affinity between them using Random Amplified Polymorphic DNA (RAPD) Marker.

\section{Materials and Methods}

\subsection{The Experimental Animals}

4 of the 8 investigated rodent specimens were brought alive from its natural habitat in Egypt either from fields around Zagazig City of Sharkia Province; black or roof rats, (Rattus rattus), homes in Sheba village of Sharkia Province; gray house mice, (Mus musculus domestics) and black mouse, (Mus musculus praetextus) and from Abu-Rawash of Giza Province spiny mouse (Acomys cahirinus). But, the laboratory albino mice (Mus musculus musculus), albino rats (Rattus rattus norvegicus), Guinea pig (Cavia porcellus) and Syrian golden hamsters, (Mesocricetus auratus) which are inbred strains introduced to animal breeders in Egypt a few decades ago and were conveyed from experimental animal facility of the Faculty of Veterinary Medicine, Zagazig University, Egypt.

In the present work, 24 rodent specimens (3 from each species) were used to compare between their DNA structures. They were transported alive to the laboratory of the Zoology Department, Faculty of Science, Zagazig University and kept in well-aerated cages under controlled laboratory conditions supplied with sufficient food and water before analysis as recommended in the guidelines given by the Institutional Ethical Committee /IRB approval in Zagazig University.

\subsection{DNA Analysis of the Studied Rodent's Species}

\subsubsection{DNA Extraction}

In the present studies, heart tissues sample from each of the studied rodent's species (Mus musculus, Mus musculus praetextus, Mus musculus domesticus, Acomys cahirinus cahirinus, Rattus norvegicus, Rattus rattus, Mesocricetus auratus and Cavia porcellus) were taken off immediately after animals had been sacrificed. The collected heart tissues sample stored in freezer till analysis of all take places.

Total genomic DNA was extracted from heart tissues using the DNeasy Tissue Kit (QIAGEN), following the manufacturer's instructions as described below:

Spin Protocol for DNA Extraction from Heart Tissue:

Buffer AW1, Buffer AW2, and QIAGEN Protease have been ensured to be properly prepared and no precipitate has formed in Buffer AL. Samples was equilibrated to $25^{\circ} \mathrm{C}$, water bath was heated to $56^{\circ} \mathrm{C}$ for use in step 4 and Buffer $\mathrm{AE}$ was equilibrated to room temperature for elution in step 11.

1- $25 \mathrm{mg}$ tissue were weighted and added to $1.5 \mathrm{ml}$ microcentrifuge tube. 2- $180 \mu \mathrm{l}$ Buffer ATL were added to the sample.

3- $20 \mu \mathrm{l}$ QIAGEN Protease (or proteinase K) was pipetted into the bottom of micro-centrifuge tube, and tissue cut into small pieces.

4- Homogenate was mixed by pulse vortexing for $15 \mathrm{~s}$ first and then thoroughly to yield a homogeneous solution.

5 - Incubation at $56^{\circ} \mathrm{C}$ for 2 hours until tissue completely digested or incubation overnight.

6- Briefly centrifuged to remove drops from the inside of the lid.

7- $200 \mu \mathrm{l}$ Buffer $\mathrm{Al}$ were added to sample, then incubation at $70^{\circ} \mathrm{C}$ for 10 minutes.

8- $200 \mu$ l ethanol (96-100\%) were added to the sample, mixed again by pulse-vortexing for fifteen second, and then briefly centrifuged to remove drops from the inside of the lid.

9- The mixture from step eight was carefully applied to the QIAamp Mini spin column (in a $2 \mathrm{ml}$ collection tube) without wetting the rim. The cap then closed, and the sample was centrifuged at 8,000 rpm for one min. The QIAamp Mini spin column was placed in a clean $2 \mathrm{ml}$ collection tube, and the tube containing the filtrate was discarded.

10- The QIAamp Mini spin column is then carefully opened and $500 \mu$ Buffer AW1 was added without wetting the rim. Cap was closed and the sample was then centrifuged at $8,000 \mathrm{rpm}$ for $1 \mathrm{~min}$. QIAamp Minispin column was placed in a clean $2 \mathrm{ml}$ collection tube, and the collection tube containing the filtrate was discarded.

11- The QIAamp Mini spin column was then carefully opened and $500 \mu$ Buffer AW2 was added without wetting the rim. The cap was then closed, and the sample was centrifuged at 14,000 rpm for $3 \mathrm{~min}$.

12- The QIAamp Mini spin column was then placed in a clean $1.5 \mathrm{ml}$ micro-centrifuge tube, and the collection tube containing the filtrate was discarded.

13- Finally, the QIAamp Mini spin column is carefully opened and $200 \mu \mathrm{l}$ Buffer AE was added, incubated at $25^{\circ} \mathrm{C}$ for $1 \mathrm{~min}$., and then centrifuged at 8,000 rpm for $1 \mathrm{~min}$. DNA samples were stored at $-20^{\circ} \mathrm{C}$ until use.

\subsubsection{Random Amplified Polymorphic DNA (RAPD)}

For RAPD analysis, five of randomly selected primers (Operon Technologies, USA) oligonucleotide primers having GC content $60-70 \%$ (Table 1 ).

The formula for primer Tm calculation: $\mathrm{Tm}=4(\mathrm{G}+\mathrm{C})+$ $2(\mathrm{~A}+\mathrm{T})={ }^{\circ} \mathrm{c}$

PCR reactions were also carried out by Techne PCR mini 
thermal cycler. Each PCR reaction mixture of $12.5 \mu \mathrm{l}$ consisted of PCR GoTaq Green Master Mix, $1 \mu$ of each oligo primer $(10 \mathrm{pmol} / \mu \mathrm{l})$ and $5 \mu \mathrm{l}$ DNA extract and the volume was brought to $25 \mu \mathrm{l}$ by deionized water, all in the rmowell® GOLD $0.2 \mathrm{ml}$ Polypropylene PCR Tubes. PCR conditions were as follows: initial denaturation (1 cycle) on $94^{\circ} \mathrm{C}$ for $5 \mathrm{~min}$ followed by 45 cycles, each one consisting of a DNA denaturation step $\left(1 \mathrm{~min}\right.$ at $\left.94^{\circ} \mathrm{C}\right)$, one primer annealing step $\left(1 \mathrm{~min}\right.$ at $\left.36^{\circ} \mathrm{C}\right)$ and a DNA extension step (2 $\min$ at $72^{\circ} \mathrm{C}$ ) and an extra final extension step was performed for $10 \mathrm{~min}$. at $72^{\circ} \mathrm{C}$ to complete amplification as recommended by [19]. PCR products were kept in $4^{\circ} \mathrm{C}$ until being electrophoresed and analyzed.

Table 1. The five RAPD Primers and their sequences.

\begin{tabular}{|c|c|c|c|c|}
\hline NO & PRIMERS & Sequence $\left(5^{\prime}-3^{\prime}\right)$ & $\begin{array}{l}G+C(\%) \\
\text { content }\end{array}$ & $\begin{array}{l}\text { Tm } \\
\text { value }{ }^{\circ} \mathrm{C}\end{array}$ \\
\hline 1 & OPN4 & $5^{\prime} \mathrm{GAC}$ CGA CCC A-3’ & $70 \%$ & $34^{\circ} \mathrm{C}$ \\
\hline 2 & OPM1 & $5^{`}$ GTT GTT GGC T -3` & $50 \%$ & $30^{\circ} \mathrm{C}$ \\
\hline 3 & OPT7 & $5^{`} \mathrm{GGC}$ AGG CTG T -3’ & $70 \%$ & $34^{\circ} \mathrm{C}$ \\
\hline 4 & OPA4 & $5^{\prime} \mathrm{AAT}$ CGG GCT G-3’ & $60 \%$ & $32^{\circ} \mathrm{C}$ \\
\hline 5 & OPG2 & $5^{\prime} \mathrm{GGC}$ ACT GAG G -3 & $70 \%$ & $34^{\circ} \mathrm{C}$ \\
\hline
\end{tabular}

\subsubsection{Agarose Gel Electrophoresis}

Reagents and Chemicals

1-Agarose powder (Fisher Scientific, UK)

2-Tris Borate EDTA buffer (TBE): for 1 litter of working 1X TBE, 10.8gm Tris base, 5.5gm boric acid (United Co., Egypt), and $0.74 \mathrm{gm}$ of EDTA (WINLAB, USA) were dissolved and the volume is brought to 1 litter by $\mathrm{ddH}_{2} \mathrm{O}$.

3-Ethidium Bromide (EthBr) stain: (Promega, USA) ready for use.

\subsubsection{Pre -stained 1.0\% Agarose Gel Preparation for Small Unit Used for separation of PCR Product}

The PCR reactions were done as mentioned by [20] with slide modification of [21]. Since, $0.5 \mathrm{~g}$ of agarose was added to $50 \mathrm{ml} \mathrm{TBE}$ buffer into a $100 \mathrm{ml}$ bottle, and dissolved in the microwave oven (Kelvinator ${ }^{\circledR}$, USA) for about 40 seconds. Solution was mixed twice during the microwaving, cooled down to $\sim 50^{\circ} \mathrm{C}$, and then $1.0 \mu \mathrm{l}$ of the Ethidium Bromide was added and mixed. The horizontal gel apparatus was sealed, and the comb was inserted until its base is $2 \mathrm{~mm}$ from the base of the gel to make pores. Molten agarose was poured onto a gel plate while avoiding bubbles. Gel tray was then inserted into the proper position in the electrophoresis chamber, after that gel stand was filled with buffer TBE until it covers the gel completely. Comb was removed and gel became ready to receive samples for electrophoresis.

\subsubsection{DNA Loading Buffer (6X) Preparation}

$30 \% \quad(\mathrm{v} / \mathrm{v})$ glycerol was added to $0.25 \% \quad(\mathrm{w} / \mathrm{v})$ bromophenol blue and $0.25 \%(\mathrm{w} / \mathrm{v})$ xylene cyanol $\mathrm{FF}$ and stored at $4^{\circ} \mathrm{C}$.

Loading Samples: $5 \mu 1$ of $6 \mathrm{X}$ loading dye were added to PCR product samples, mixed well and then the mixture was injected into the gel pores (wells).

Running Agarose Gel: Gel was run in Minicell horizontal electrophoretic unit 8 wells (UNITEC, EC-370M, USA) at a constant current $100 \mathrm{~V}$ for $\sim 1$ hour until bromophenol blue passes $\sim$ two third the gel distance.

Gel Visualization and Analysis: The gels were then visualized using UV transilluminator (Upland CA.91786, M20, USA) and were photographed using Digital Camera. Images were formatted and analyzed by "Gel-Pro $® 3.1$ " analyser software. The molecular weight (size) was determined by using 100 base pair DNA ladder marker (Solis BioDyne, Riia, Tartu, Estonia) from 100-3000 bp MW as a standard ( $3 \mu 1$ loaded), which is loaded and migrated the same gel with samples.

\section{Results}

The current study applied using RAPD-PCR where, five random decamer RAPD primers were screened to produce banding patterns in the eight samples of genomic DNA constituted of albino mouse, house mouse, black mouse, spiny mouse, albino rat, black rat, hamster and guinea pigs. So universal primers fitting to rodents were selected, since the RAPD profile of the different studied species of mice, rats, hamster and guinea pigs were greatly dissimilar.

The primers OPA-4, OPT-7, OPG-2, OPN-4 and OPM-1 appeared to be the most useful for detection of genus specific population. These five arbitrary short primers to differentiate between the different studied species produced 74 polymorphic, reproducible and mark-able bands. The maximum number of bands 23 was produced with primer OPA-4 (Figure 1) but the minimum number of bands 9 was created with primer Opt7 (Figure 2). However, the primers OPN-4, OPG-2 and OPM-1 generated 19, 11 and 12 reproducible bands, respectively (Figures 3, 4, 5, 6).

All of these scored bands are polymorphic (100\%) and none of them showed mono-morphism. The used primers; OPA-4, OPG-2 produced the highest percentage (100\%) of polymorphic bands, meanwhile short primers OPT-7, OPN-4 and OPM-1 produced only $89.0 \%, 94.7 \%, 92.0 \%$ of polymorphic bands, respectively. The unique fragments were produced by OPT-7, OPN-4 and OPM-1 primers.

The molecular weight of the amplified bands was ranged from $50 \mathrm{bp}$ to $650 \mathrm{bp}$. The maximum size-range of amplified products 200-650 for a single primer was found with OPA-4, whereas the minimum 100-300 bp was as obtained with Opt7 (Table 2, Figure 7).

Nei's Genetic Distance (D)

We can calculate genetic distance by the equation of $\mathrm{Ni}$ and $\mathrm{Li}$ [22]

$$
\mathrm{GD}=1-[2 \mathrm{Nab} /(\mathrm{Na}+\mathrm{Nb})]
$$

Since: $\mathrm{Na}=$ number of bands in species $\mathrm{a}, \mathrm{Nb}=$ number of bands in species $\mathrm{b}$ and $\mathrm{Nab}=$ number of common bands in species aand $b$ [23].

The highest genetic distance (1) was found between albino rat (R. $r$. norvegicus) \& black mouse (M. m. praetextus) and between house mouse (M. m. domesticus) \& albino rat (R. $r$. norvegicus) distantly related. This is followed by the genetic distance between Syrian hamster (Mesocricetus auratus) and 
house mouse (M. m. domesticus) as well as between guinea pig (Cavia porcellus) and albino rat ( $R$. $r$. norvegicus). Nonetheless, the lowest genetic distance 0.31 was noticeable between black mouse (M. m. praetextus) and albino mouse (M. m. musculus) close related (Table 3).

Phylogenetic Relationships Using Euclidean Distance:

The dendrogram for the studied eight rodents subspecies based on Euclidean genetic distance were showed in (Figure 8).

There were Five Separate Clusters:

1-Black mouse (M. m. praetextus) and albino mouse ( $M$. m. musculus) clustered together in the first one.

2-Guinea pig (Cavia porcellus) clustered separately in second cluster.

3-Spiny mouse (Acomys cahirinus) and house mouse ( $M$. $m$. domesticus) clustered together in third cluster,

4-Syrian hamster (Mesocricetus auratus) and albino rat (Rattus norvegicus) clustered together in fourth cluster.

5-Black rat (Rattus. rattus rattus) clustered separately in fifth cluster.

Table 2. Characteristic of fragments generated by the primers selected for the RAPD analysis. Number of Amplified Bands per Morphotype (NA Bands/ Morphotype), Total Number of Amplified Bands (TNA Bands), Band Frequency per Primer (Band Freq. / Primer), Number of Polymorphic Bands (NP Bands), Number of Monomorphic Bands (NM Bands), Polymorphic Percentage (\%POL) and Range of Amplified Fragment in base pair (RAF bp).

\begin{tabular}{|c|c|c|c|c|c|c|c|c|c|c|c|c|c|c|c|}
\hline \multirow[b]{2}{*}{ Primer code } & \multicolumn{8}{|c|}{$\mathrm{NAB} /$ animal species } & \multirow[b]{2}{*}{ TNAB } & \multirow{2}{*}{$\begin{array}{l}\text { Band } \\
\text { Freq. / } \\
\text { Primer }\end{array}$} & \multirow[b]{2}{*}{ NUB } & \multirow[b]{2}{*}{ NPB } & \multirow[b]{2}{*}{ NMB } & \multirow[b]{2}{*}{$\begin{array}{l}\% \\
\text { POL }\end{array}$} & \multirow[b]{2}{*}{ RAF (bp) } \\
\hline & $\begin{array}{l}\text { Black } \\
\text { mouse }\end{array}$ & $\begin{array}{l}\begin{array}{l}\text { Albino } \\
\text { mouse }\end{array} \\
\end{array}$ & $\begin{array}{l}\text { House } \\
\text { mouse }\end{array}$ & $\begin{array}{l}\text { Spiny } \\
\text { mouse }\end{array}$ & $\begin{array}{l}\text { Albino } \\
\text { rat }\end{array}$ & $\begin{array}{l}\text { Black } \\
\text { rat }\end{array}$ & Hamster & $\begin{array}{l}\text { Guinea } \\
\text { pig }\end{array}$ & & & & & & & \\
\hline OPA4 & 5 & 5 & 1 & 2 & 0 & 5 & 3 & 2 & 23 & 0.3108 & 0 & 23 & 0 & $100 \%$ & $200-650$ \\
\hline OpT7 & 1 & 1 & 1 & 1 & 1 & 1 & 1 & 2 & 9 & 0.1216 & 1 & 9 & 0 & $89.0 \%$ & $100-300$ \\
\hline OPN4 & 1 & 2 & 2 & 2 & 1 & 5 & 3 & 3 & 19 & 0.2567 & 1 & 19 & 0 & $94.7 \%$ & $50-450$ \\
\hline OPG2 & 2 & 2 & 1 & 0 & 1 & 2 & 1 & 2 & 11 & 0.1486 & 0 & 11 & 0 & $100 \%$ & $250-400$ \\
\hline OPM1 & 3 & 1 & 2 & 2 & 0 & 2 & 1 & 1 & 12 & 0.1621 & 1 & 12 & 0 & $92.0 \%$ & $100-450$ \\
\hline Total & 12 & 11 & 7 & 7 & 3 & 15 & 9 & 10 & 74 & & & & & & \\
\hline $\begin{array}{l}\text { Band Freq. / } \\
\text { morphotype }\end{array}$ & 0.16 & 0.15 & 0.09 & 0.09 & 0.04 & 0.20 & 0.12 & 0.13 & & & & & & & \\
\hline
\end{tabular}

Table 3. Genetic distances between rodent species using RAPD data.

\begin{tabular}{|c|c|c|c|c|c|c|c|c|}
\hline & Black mice & Albino mice & House mice & Spiny mice & Albino rat & Black rat & Hamster & Guinea pig \\
\hline Black mice & 0 & 0.31 & 0.79 & 0.8 & 1 & 0.63 & 0.81 & 0.41 \\
\hline Albino mice & & 0 & 0.81 & 0.78 & 0.72 & 0.62 & 0.5 & 0.53 \\
\hline House mice & & & 0 & 0.43 & 1 & 0.55 & 0.87 & 0.65 \\
\hline Spiny mice & & & & 0 & 0.8 & 0.82 & 0.63 & 0.77 \\
\hline Albino rat & & & & & 0 & 0.78 & 0.5 & 0.85 \\
\hline Hamster & & & & & & & 0 & 0.68 \\
\hline Guinea pig & & & & & & & & 0 \\
\hline
\end{tabular}

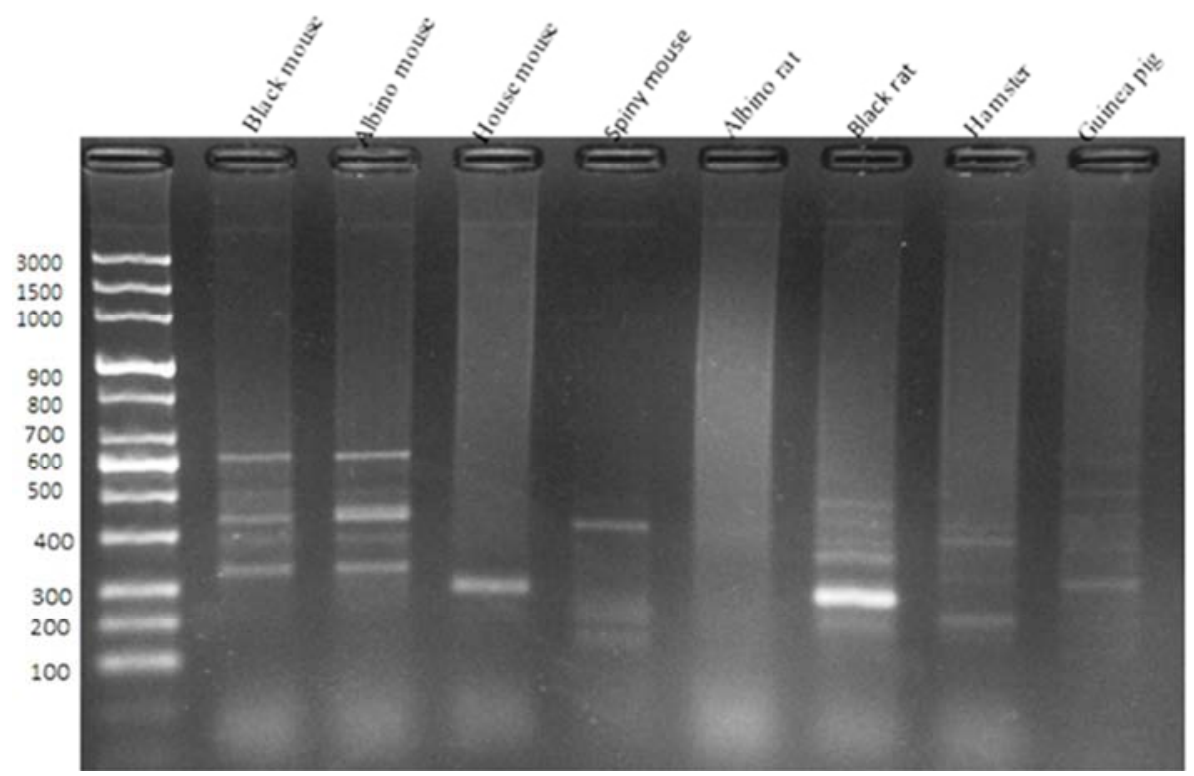

Figure 1. Gel electrophoresis for PCR-product amplified using primer OPA4. 


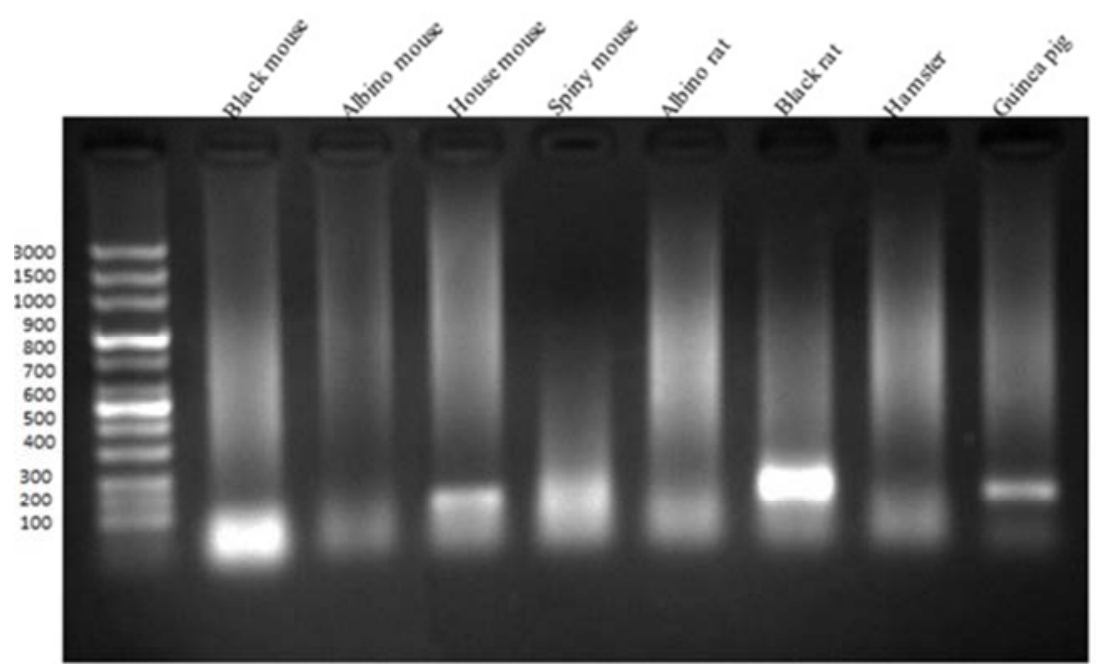

Figure 2. Gel electrophoresis for PCR-product amplified using primer OpT7.

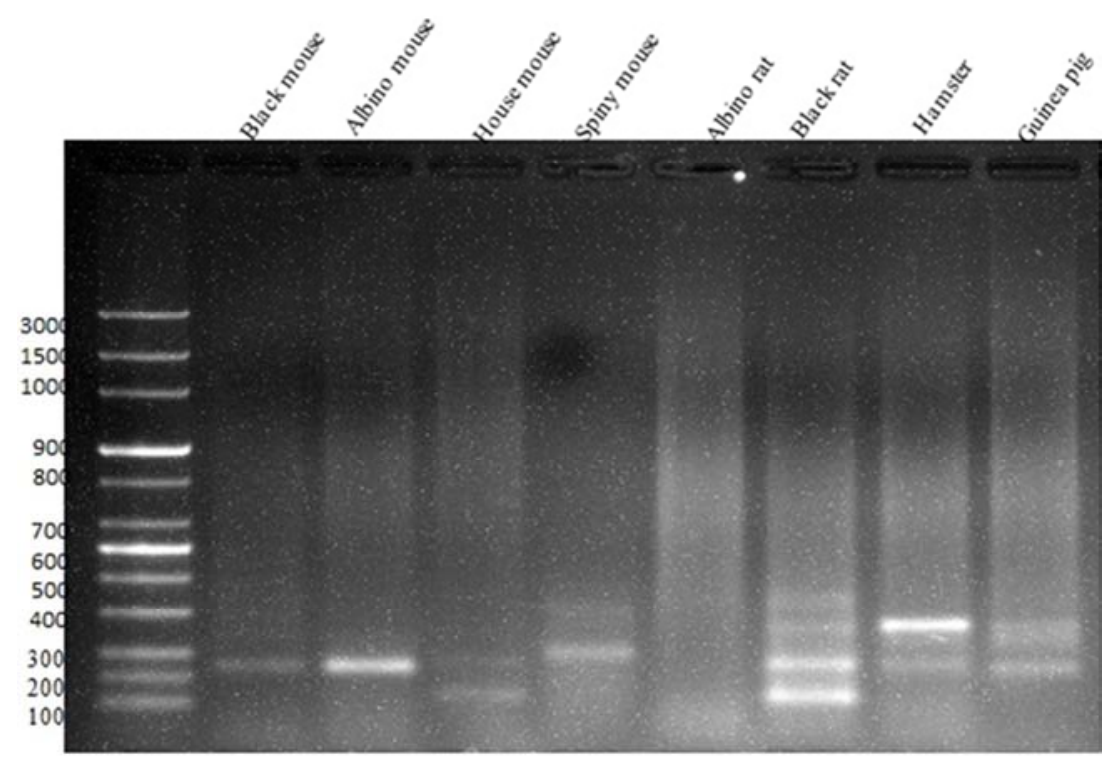

Figure 3. Gel electrophoresis for PCR-product amplified using primer OpN4.

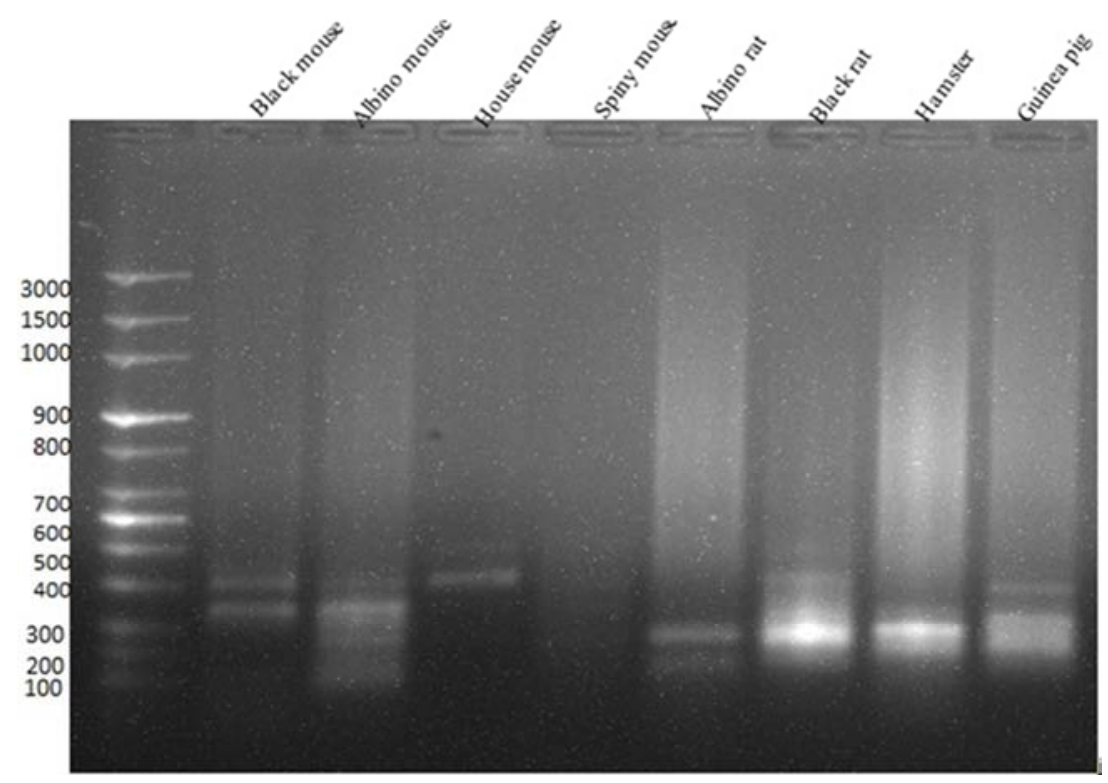

Figure 4. Gel electrophoresis for PCR-product amplified using primer OpG2. 


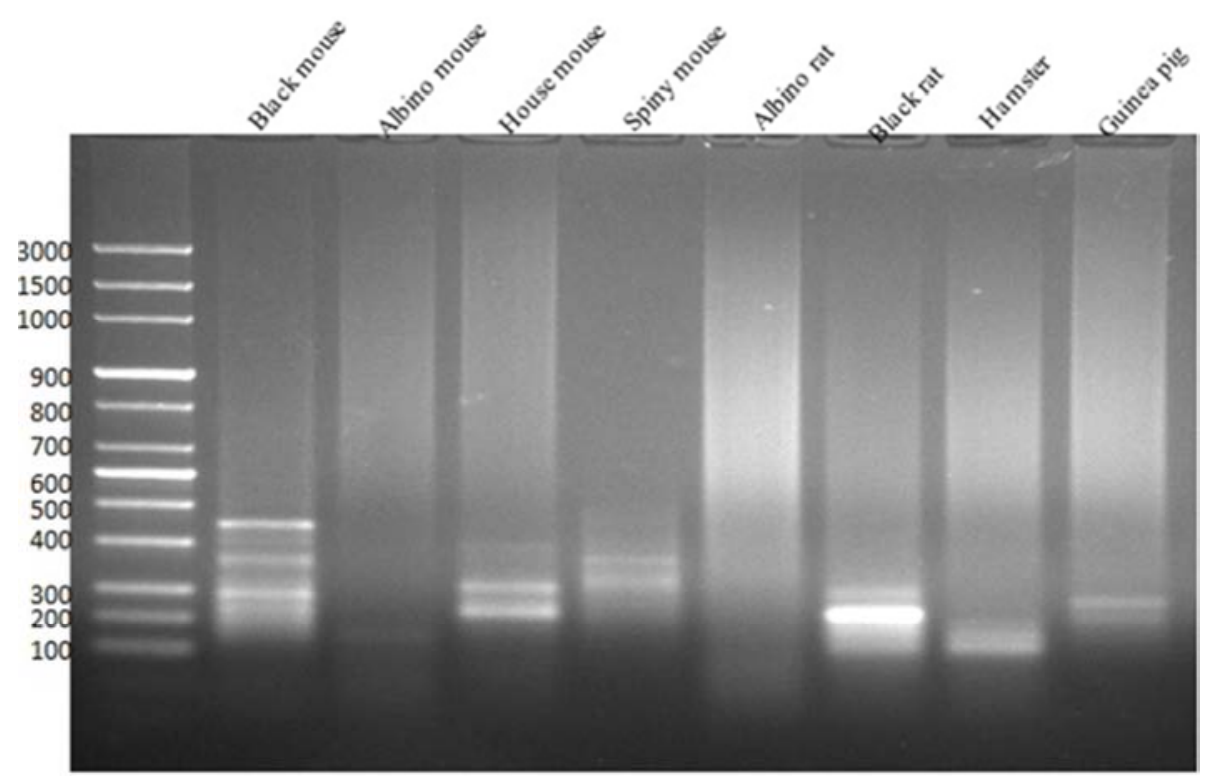

Figure 5. Gel electrophoresis for PCR-product amplified using primer OpM1.

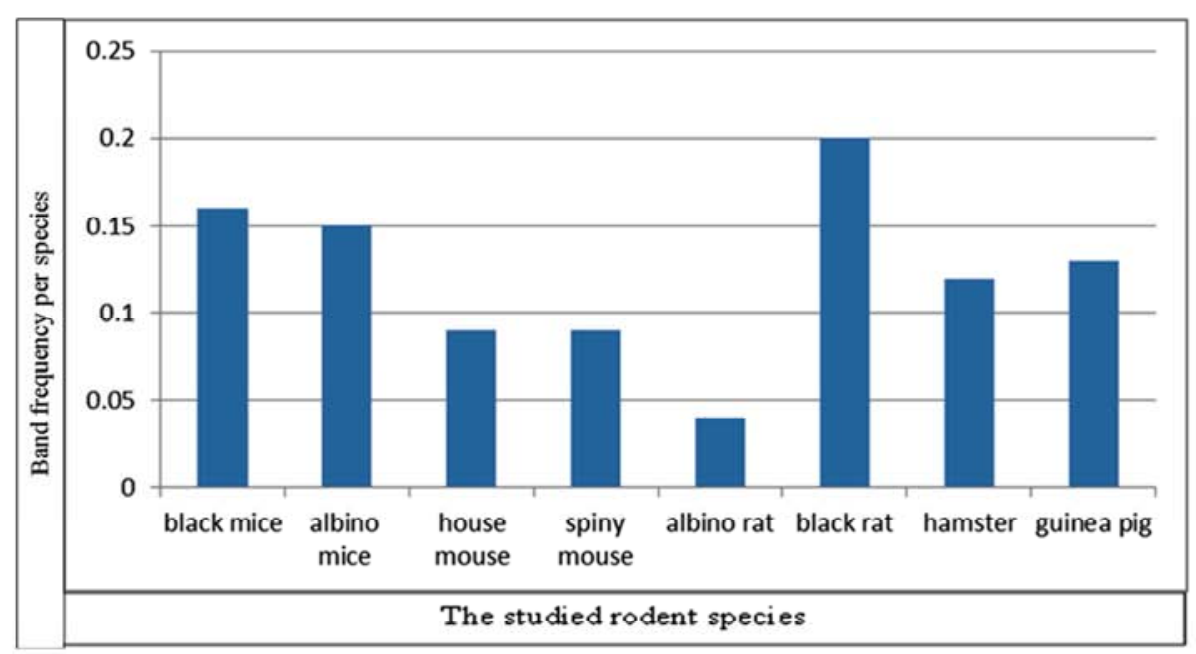

Figure 6. Band frequencies recorded for the rodent species.

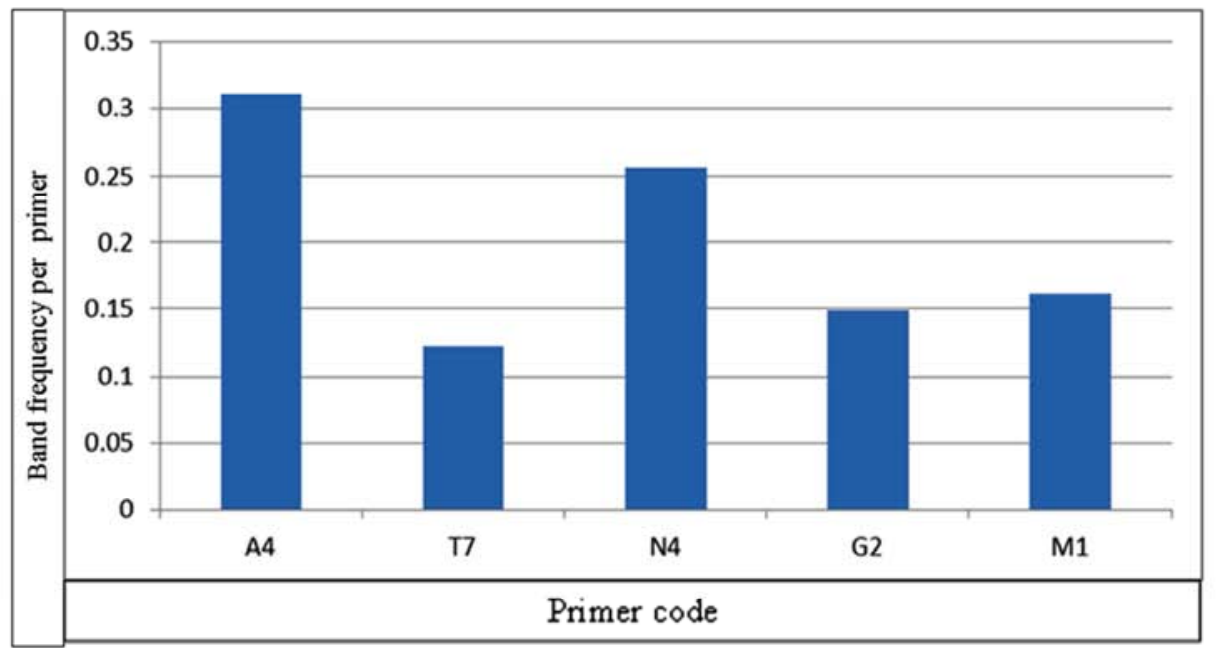

Figure 7. Band frequencies recorded per the 5 deca-nucleotide primers. 


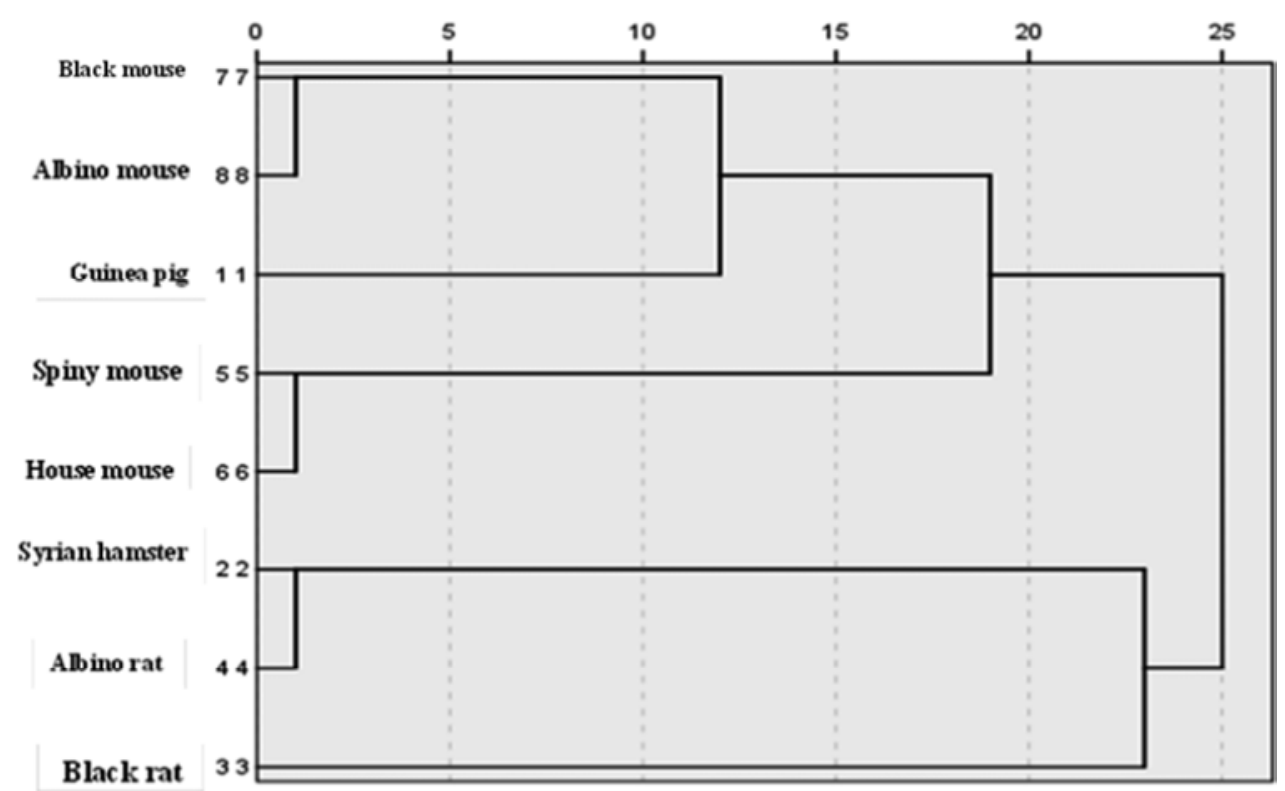

Figure 8. Dendrogram of studied rodents based on genetic distances among them.

\section{Discussion}

In the present study, the genomic DNA sequences for Mus musculus, Mus musculus praetextus, Mus musculus domesticus, Acomys cahirinus cahirinus, Rattus norvegicus, Rattus rattus, Mesocricetus auratus and Cavia porcellus were analyzed.

This was supported [24, 25] who recorded that it is possible to use of DNA analyses to compare chromosomes directly at the DNA level. Using cladistics analysis rearrangements that have differentiated the rodent's karyotype were then more exactly mapped and placed in a phylogenomic outlook. Comparative chromosomes are a new term that was used to define the field of cytogenetic dealing with recent molecular approaches although chromosomes were originally defined the chromatin dynamics and morphological changes in interphase chromosome structures.

In the modern taxonomy, classification and identification many processes are applied. In this context, DNA analysis moved forward from just identification and becoming a service technique important for aspects of taxonomy and origin, even being relevant in other biological areas, ranging from distribution to conservation and behavior. DNA analysis is a universal molecular identification system for living organisms. Its effectiveness has been confirmed recently, since it is common to link DNA specific to the animal's species with phylogenetic reconstruction, which probably led to discovering of new animal species. Mammals are one of the important animal groups achieved this purpose, since Mammals are represent with about 5564 species listed in the Catalogue of Life, ITIS database [26, 27].

Herein, RAPD markers were used to detect genetic differences between the eight rodent subspecies. The RAPD and other molecular assay showed to be manful for taxonomic relationships and genetic diversity studies. All the used five decanucleotide random primers produced at test
$(100 \%)$ polymorphic fragments and none of them showed monomorphic bands indicating the successful PCR use here far revealing instructive RAPD banding pattern and indicated that in genetic relatedness among the eight rodent subspecies.

It was found that, from all five used primers, primer OPA4 exhibited highest primer band frequency is 0.3108 while the lowest value is 0.1216 recorded from primer OPT7 interesting the high molecular fragment of about 650 recorded for black and albino mouse with primer OPA4. This band was not observed in others species which indicated the presence of internal genetic variation, and closed relation between the two subspecies.

Also the two subspecies (black \& albino mouse) recorded 4 bands variation between 300 and 500. This confirms a strong intragenic relationship between the two subspecies. These data were supported by [28-30] since they observed the same intragenic relation between nuclear and mitochondria data within Mus of Asian group.

Nonetheless, the present data for the studied eight rodent species showed the presence of molecular fragment $400 \mathrm{bp}$ in (Black and Albino mouse, spiny mouse and Syrian hamster) also fragment 200bp in (Spiny mouse, Black rat and Hamster) and fragment $300 \mathrm{bp}$ in (Black and albino mouse also Black rat and Guinea pig).

All data revealed an intragenic relation between the eight rodent species, which are agreement with several result recorded by [31] who stated that there are strong phylogenic and divergence for major Rodent groups within multiple genes.

Nonetheless, [32] concluded that, the primers with $\mathrm{G}+\mathrm{C}$ content generates more number of polymorphic bands in the three subspecies (mice, rat and guinea pig).

The maximum number of polymorphic band was recorded in guinea pig while mice scored minimum number of polymorphic bands. An average band frequency value the maximum heterogeneity and homogeneity were recorded in 
black rat, Black \& Albino mice. This indicated high rate of homogeneity and heterogeneity $(0.20,0.16 \& 0.15)$ and the lowest rate were recorded in albino rat (0.04).

These data were contrasted with data recorded by $[33,34]$ recorded a very low level of genetic diversity in house mice and high genetic diversity in guinea pig i.e. the heterogeneity more in guinea pig than rat and mice.

The designed dendrogram depicted unambiguous grouping of samples consistent with their genus, the high genetic distance existed between (Albino rat, Black mice \& Hamster) followed by (Hamster\& house mouse as well as Guinea pig $\&$ Albino rat similarly Spiny mouse \& Hamster). Nonetheless, the low genetic distance is existed between (Black mice \& Albino mice).

These results donated to the taxonomy of the eight rodent subspecies, in which Black, House \& Albino mice under the same species Mus musculus while Albino rat \& black mice under the same sub family Murinae. Also albino rat, black mice and hamster belong to super family Muridae. In addition Albino rat, Spiny mouse \& Hamster are under the same super family Muridae.

These results are in agreement with many authors who supported the utility of genetic distance to categorize and explain the evolutionary link between populations, degree of genetic variation in addition to history of animals. Also, the significance of using the genetic distance measures to calculate biodiversity, population structure and genetic changes in white Pekin and Muscovy duck [35- 37].

\section{Conclusion}

According to the results of the present investigation, dendrogram between the eight studied rodents species spread in the Egyptian climate based on Euclidean genetic distance explained that, there were five separate clusters; Black mouse (M. m. praetextus) and albino mouse (M. m. musculus) clustered together in the first one, Guinea pig (Cavia porcellus) clustered separately in second cluster, Spiny mouse (Acomys cahirinus) and house mouse (M. m. domesticus) clustered together in third cluster, Syrian hamster (Mesocricetus auratus) and albino rat (Rattus norvegicus) clustered together in fourth cluster, Black rat (Rattus. rattus rattus) clustered separately in fifth cluster.

\section{References}

[1] Stenseth N C, Leirs H, Skonhoft A, Davis S A, Pech R P et al 2003 Mice, rats, and people: the bio-economics of agricultural rodent pests. Front Ecol Environ 1 (7): 367-75

[2] Singleton G R 2003 Impacts of rodents on rice production in Asia. IRRI Discussion Paper Series No. 45, Los Banos, Phillippines: $30 \mathrm{pp}$.

[3] Fayenuwo J O, Olakojo S A, Akande M, Amusa N A, Olujimi O A 2007 Comparative evaluation of vertebrate pest damage on some newly developed quality protein maize (QPM) varieties in south-western Nigeria. Afri J Agri Res (2): 59295.
[4] Tsepo R, Nthabiseng M, Kutswa G, Moeti O T, Oriel M M et al 2019. Identification of Rodent Species That Infest Poultry Houses in Mafikeng, North West Province, South Africa. International Journal of Zoology, 2019 (1): 1-8.

[5] Schlick NE, Jensen-Seaman MI, Orlebeke K, Kwitek AE, Jacob HJ, Lazar J 2006 Sequence analysis of the complete mitochondrial DNA in 10 commonly used inbred rat strains. Amer. J Physiol Cell Physiol (291): 1183-1192.

[6] Francis CM, Borisenko AV, Ivanova NV, Eger JL, Lim BK, et al 2010 The role of DNA barcodes in understanding and conservation of mammal diversity in Southeast Asia. PLoS One 5 (9): e12575.

[7] Huffman JE, Wallace JR 2012 Wildlife Forensics: Methods and applications. Huffman, Jane E. and Wallace, John R. eds., $1^{\text {st }}$ Edition, Wiley and Blackwell: 396 pp.

[8] Amori G, Clout M 2003 Rodents on islands: a conservation challenge. In: Rats, mice and people: rodent biology and management, (eds) GR Singleton, LA Hinds, CJ Krebs, DM Spratt, Australian Centre for International Agricultural Research, Canberra: 63-68.

[9] Puillandre N, Bouchet P, Boisselier-Dubale MC, Brisset J, Buge B, et al 2012 New taxonomy and old collections: integrating DNA barcoding into the collection curation process. Mol Ecol Resour 12 (3): 396-402.

[10] Vesterinen EJ, Lilley T, Laine VN, Wahlberg N 2013 Next generation sequencing of fecal DNA reveals the dietary diversity of the widespread insectivorous predator Daubenton's Bat (Myotis daubentonii) in Southwestern Finland. PLoS One 8 (11): e82168.

[11] Hope PR, Bohmann K, Gilbert MTP, Zepeda-Mendoza ML, Razgour O, Jones G 2014 Second generation sequencing and morphological faecal analysis reveal unexpected foraging behaviour by Myotis nattereri (Chiroptera, Vespertilionidae) in winter. Front Zool 11 (1): 39 pp.

[12] Burgar JM, Murray DC, Craig MD, Haile J, Houston J et al 2014 Who's for dinner? High-throughput sequencing reveals bat dietary differentiation in a biodiversity hotspot where prey taxonomy is largely undescribed. Mol Ecol 23 (15): 3605-3617.

[13] Kruger F, Clare EL, Symondson WO, Keiss O, Petersons G 2014 Diet of the insectivorous bat, Pipistrellus nathusii, during autumn migration and summer residence. Mol Ecol 23 (15): 3672-3683.

[14] Sedlock JL, Kruger F, Clare EL 2014. Molecular Ecology (Special issue): Molecular Detection of Trophic Interactions. Island bat diets: does it matter more who you are or where you live?. Mol Ecol 23 (15): 3684-3694.

[15] Boyer S, Cruickshank RH, Wratten SD 2015 Faeces of generalist predators as biodiversity capsules: A new tool for biodiversity assessment in remote and inaccessible habitats. Food Webs (3): 1-6.

[16] De Pasquale PP, Galimberti A 2014 New records of the Alcathoe bat, Myotis alcathoe (Vespertilionidae) for Italy. Barbastella (7): 1 p.

[17] Wilson JJ, Sing KW, Halim MRA, Ramli R, Hashim R et al 2014). Utility of DNA barcoding for rapid and accurate assessment of bat diversity in Malaysia in the absence of formally described species. Genet Mol Res 13 (1): 920-925. 
[18] Johnson RN, Wilson-Wilde L, Linacre A 2014 Current and future directions of DNA in wildlife forensic science. Forensic Sci Int-Gen (10): 1-11.

[19] Gehlot P, Purohit DK 2011 Molecular diagnostic of human pathogenetic Aspergillus species. Indian J Biotechnol (10): 207-211.

[20] M, Dubey N, Totey SM 2002 Phylogenetic relationships and genetic polymorphisms in wild Indian mice. Biomol Eng (18): 281-288.

[21] Williams JGK, Kubelik AR, Livak KJ Rafalski JA, Tingey SV 1990 DNA polymorphisms amplified by arbitrary primers are useful as genetic markers. Nucleic Acids Res 18 (22): 65316535 .

[22] Ni M, Li WH 1979 Mathematical model for studying genetic variation in terms of restriction Endonucleases. Proc National Acad of Sci USA 76 (10): 5269-5273.

[23] Farman AA, Aboud MN 2015 Biodiversity and Genetic Relationships to the Species for the genus Gladiolus $\mathrm{L}$. (Iridaceae) Wild Growing in Iraq Using RAPD-PCR Technique. Ibn Al-Haitham J for Pure and Appl Sci 28 (3): 373-382.

[24] Graphodatsky AS, Trifonov VA, Stanyon R 2011 The genome diversity and karyotype evolution of mammals. Molecular Cytogenetics 4 (22): 1-16.

[25] Claussen U 2005 Chromosomics. Cytogenet Genome Res (111): 101-106.

[26] Casiraghi M, Labra M, Ferri E, Galimberti A, De Mattia F 2010 DNA barcoding: a six question tour to improve users' awareness about the method. Brief Bioinform 11 (4): 440-453.

[27] Galimbertia A, Sandionigia A, Brunoa A, Bellatib A, Casiraghia M 2015 DNA barcoding in mammals: what's new and where next? Hystrix, Italian J Mammal, Publ Assoc Teriol Italiana 26 (1): 13-24.
[28] She JX, Bonhomme F, Boursot P, Thaler L, Catzeflis F 1990 Molecular phylogenies in the genus Mus: Comparative analysis of electrophoretic, scnDNA hybridization, and mtDNA RFLP data. Biol J Linn Soc (41): 83-103.

[29] Lum JK, Cann RL, Martinson JJ, Jorde LB 1998 Mitochondrial and nuclear genetic relationships among Pacific Island and Asian populations. Am J Hum Genet 63 (2): 613-624.

[30] Guenet JL, Bonhomme F 2003 Wild mice: an ever-increasing contribution to a popular mammalian model. Trends in Genetics 19 (1): 24-31.

[31] Adkins RM, Gelke EL, Rowe D, Honeycutt RL 2001 Molecular phylogeny and divergence time estimates for major rodent groups: Evidence from multiple Genes. Molecular Biol Evol 18 (5): 777-791.

[32] Dinesh KR, Chan WK, Lim TM Phange VE 1995 RAPD markers in fishes: an evaluation of resolution and reproducibility. Asia-Pac J Mol Biol Biotechnol (3): 112-118.

[33] Cui S, Chesson C, Hope R 1993 Genetic variation within and between strains of outbred Swiss mice. Lab Anim (27): 116123.

[34] Spiridonova LN, Chelomina GN, Moriwaki K, Yonekawa H, Bogdanov AS 2004 Genetic and taxonomic diversity of the house mouse, Mus musculus, from the Asian Part of the former Soviet Union. Rus J Genet (40): 1134-1143.

[35] Ruane J 1999 A critical review of the value of genetic distance studies in conservation of animal genetic resources. J Anim Breed Genet (116): 317-323.

[36] Nagamine Y, Higuchi M 2001 Genetic distance and classification of domestic animals using genetic markers. J Anim Breed Genet (118): 101-109.

[37] Dolmatova IY, Saitbatalov TF, Gareev FT 2000 Study of genetic polymorphism using randomly amplified polymorphic DNA in ducks: differences between breeds. Genet Moskva (36): 682-687. 